\title{
Morfometrik Tubuh Serta Persentase Karkas dan Non Karkas Kerbau Rawa dan Sapi PO Hasil Penggemukkan Secara Feedlot
}

\author{
Morfometric and Carcass and Non Carcass Percentage of Swamp Buffalo and PO Cattle in Feedlot \\ System \\ G. Siamtiningrum ${ }^{1)}$, B. W. Putra ${ }^{2)}$ dan R. Priyanto ${ }^{2)}$ \\ ${ }^{1)}$ Fakultas Peternakan, InstitutPertanian Bogor \\ ${ }^{2)}$ Departemen Ilmu Produksidan Teknologi Peternakan, Fakultas Peternakan, Institut Pertanian Bogor, J1. \\ Agatis, Kampus IPB Dramaga, Bogor 16680, Indonesia
}

\begin{abstract}
Buffalo has anatomical similarity with cattle, such as rument and body frame. The objective of this study were to body measurement and percentage of carcass and non carcass of swamp buffaloes and PO cattles in the feedlot system. Six heads male of Swamp Buffalo $(218 \mathrm{~kg})$ and eight heads male of PO Cattle $(217 \mathrm{~kg})$ were maintained in the feedlot system for 10 weeks. The body size was measured during the maintenance and percentage of carcass and non carcass were taken from the calculations of carcass/non carcass weight per live weight $\times \mathbf{1 0 0} \%$, data was analyzed using t-test method. The results showed that various parts of the body measurement was significant $(\mathrm{P}<0.05)$, percentage of carcass was too significant $(\mathrm{P}<0.01)$, and percentage of non carcass was not significant $(\mathrm{P}>0.05)$.
\end{abstract}

Key words: body measurement, carcass, feedlot, non carcass, PO cattle, swamp buffalo.

\section{PENDAHULUAN}

Kerbau adalah ternak yang memiliki kemiripan anatomi dengan sapi, yaitu pada rumen dan juga kerangka tubuhnya. Namun, pemanfaatan kerbau di Indonesia masih belum maksimal, hanya sebatas hewan pekerja saja. Sistem pemeliharaan kerbau juga masih dilakukan dengan cara digembalakan. Pada penelitian ini, sistem pemeliharaan yang digunakan terhadap kerbau sama dengan sapi penggemukan pada umumnya, yaitu secara feedlot, kemudian akan dilihat perbedaan antara keduanya pada morfometrik tubuh dan juga presentase karkas dan non karkasnya. Pemeliharaan ternak secara feedlot diharapkan dapat meningkatkan kualitas performa pertumbuhan dan persentase karkas dari ternak kerbau maupun sapi dengan pemberian pakan yang efisien.

Kebutuhan masyarakat Indonesia terhadap daging merah semakin meningkat. Konsumsi daging merah masyarakat yang hanya terfokus pada hasil produksi daging beberapa ternak seperti sapi, kambing, dan domba menimbulkan permasalahan karena terdapat kesenjangan antara produksi dan konsumsi daging merah dalam negeri. Peternak dalam negeri tidak mampu mencukupi kebutuhan daging merah nasional sehingga pemerintah melakukan impor sebagai solusi untuk mengatasi permasalahan yang ada. Dalam penelitian ini ternak ruminansia besar lain seperti kerbau diharapkan dapat melengkapi peran sapi sebagai penghasil daging merah di Indonesia.

Morfometrik tubuh ternak dapat dijadikan acuan untuk menduga bobot ternak. Ukuran tubuh ini pun dapat dijadikan penduga terhadap karkas yang dihasilkan oleh ternak tersebut, hal ini berhubungan dengan komposisi perdagingan suatu ternak. Penelitian mengenai morfometrik tubuh ternak rumansia besar lokal, terutama kerbau rawa Indonesia, dibandingkan dengan yang selama ini sudah biasa belum banyak dilakukan. Penelitian ini bertujuan untuk mengetahui perbedaan morfometrik yang dipengaruhi jenis ternak terhadap morfometrik tubuh serta persentase karkas dan non karkas pada kerbau rawa dan sapi Peranakan Ongol (PO) yang dipelihara secara feedlot.

\section{MATERI DAN METODE}

Waktu dan Tempat Penelitian

Penelitian ini dilaksanakan pada bulan Juni sampai September 2011. Penelitian ini dilakukan di Laboratorium Ruminansia Besar Fakultas Peternakan Institut Pertanian Bogor, Laboratorium Lapang Blok A Fakultas Peternakan Institut Pertanian Bogor, dan RPH (Rumah Potong Hewan) Elders.

\section{Bahan}

Ternak yang digunakan dalam penelitian ini meliputi 6 ekor kerbau rawa jantan dengan bobot awal ratarata $218 \mathrm{~kg}$ dan 8 ekor sapi PO jantan dengan bobot awal rata-rata $217 \mathrm{~kg}$, kedua jenis ternak berumur 2,5 tahun (i2). Gambar 1 dan 2 merupakan gambar ternak yang dipelihara di kandang dengan sistem feedlot.

\section{Alat}

Peralatan yang digunakan untuk menunjang terlaksananya penelitian ini antara lain yaitu kandang pemeliharaan, alat-alat kandang, pisau daging, timbangan 


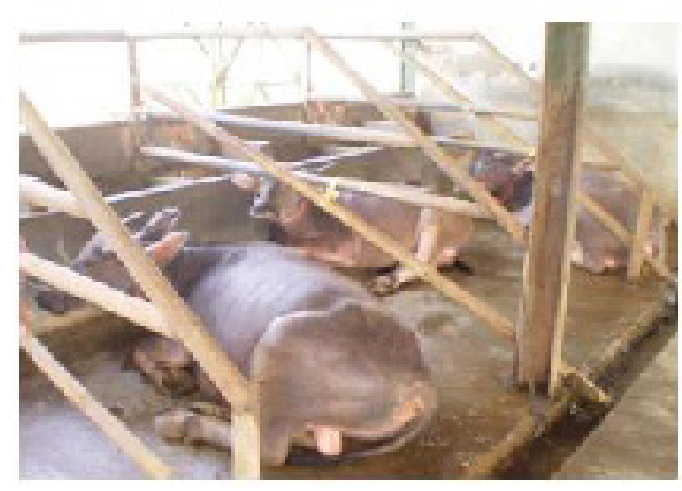

Gambar 1 Kurba rawa dalam kandang individu

digital, tali ukur dan tongkat ukur.

\section{Prosedur}

\section{Prosedur Pemeliharaan Ternak}

Sistem pemberian pakan pada setiap ternak sapi dan kerbau dibagi menjadi 2 kali sehari pada jam: 06.0008.00 dan 16.00-18.00. Pemberian pakan: $10 \mathrm{~kg}$ hijauan, $4 \mathrm{~kg}$ konsentrat, $1 \mathrm{~kg}$ kulit ari tempe. Pakan hijauan dan konsentrat diberikan sesuai dengan kebutuhan ternak berdasarkan Tabel 1 .

Kerbau yang dipelihara secara intensif di kandang perlu dirawat secara khusus. Tingkah laku kerbau yang biasa berkubang disesuaikan dengan disiram 2 kali sehari pada siang hari. Jika kerbau terjangkit kutu, maka kerbau dapat disemprot dengan cairan pembasmi serangga.

\section{Prosedur Pengukuran Tubuh Ternak}

Pengukuran dilakukan pada beberapa bagian tubuh ternak antara lain: bagian tubuh utama, alat gerak depan, alat gerak belakang, dan sumbu tubuh. Tubuh utama terdiri atas: panjang badan, tinggi badan, tinggi hips, tinggi badan terendah, dalam dada, jarak kaki depan dengan belakang, lebar badan, lebar pinggul, lingkar dada, lingkar perut besar, dan lingkar pinggul. Alat gerak depan meliputi: panjang os scapula, panjang os humerus, panjang os radius ulna, panjang os metacarpal, panjang phalanges depan, lingkar paha depan, lingkar metacarpal, dan lingkar carpus, sedangkan alat gerak belakang meliputi : lebar iscium, jarak pubis, panjang os fomoris, panjang tulang tibia fibula, panjang os metatarsal, panjang phalanges belakang, lingkar paha belakang, lingkar tarsus, dan lingkar metatarsal. Sumbu tubuh ternak terdiri atas: panjang tulang leher, panjang os toracis, panjang lumbar, panjang sacrum, dan tinggi sacrum bagian belakang. Morfometrik tubuh ternak diukur saat akhir pemeliharaan, sesuai

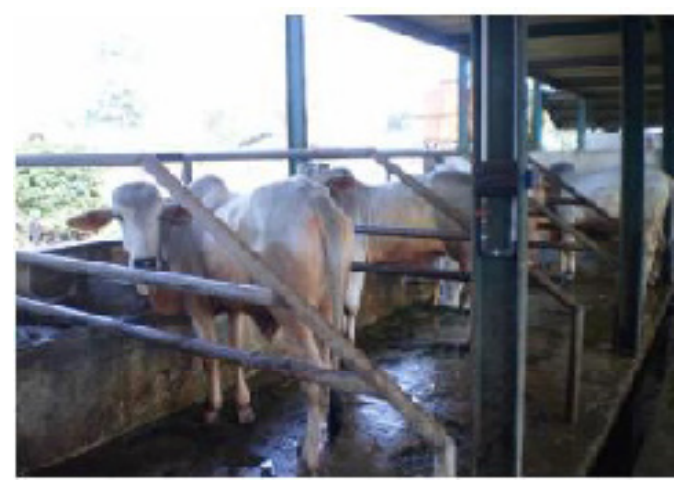

Gambar 2 Sapi PO dalam kandang individu

dengan ilustrasi pengambilan data morfometrik ternak pada Gambar 3 dan keterangan pada Tabel 2.

\section{Prosedur Penyembelihan Ternak dan Penimbangan} Karkas dan Non Karkas

Sapi dan kerbau yang sudah habis masa pemeliharaannya siap disembelih

dan dipotong. Ternak dipuasakan selama kurang lebih 24 jam untuk mengurangi isi saluran pencernaan. Setelah itu ditimbang untuk menentukan bobot potongnya. Penyembelihan dilakukan secara syariat Islam dengan memotong bagian leher dekat tulang rahang bawah agar pendarahan terjadi sempurna. Kepala dilepaskan pada sendi Occipito-atlantis, dan ditimbang sebagai bobot kepala. Kaki depan dilepaskan pada sendi Carpo-metacarpal, sedangkan kaki belakang dilepaskan pada sendi Tarsometatarsal saat ternak sudah digantung. Keempat kaki tersebut ditimbang sebagai bobot kaki depan dan belakang. Pelepasan kulit dilakukan dengan diiris dari leher sampai bagian anus dan dari arah kaki depan dan belakang menuju irisan tadi. Kulit yang telah dilepaskan ditimbang sebagai bobot kulit.

Pengeluaran isi rongga perut dan dada dilakukan dengan menyayat dinding abdomen sampai dada. Pada saat ini ekor dipisahkan dari tubuh dan ditimbang. Semua organ tubuh yang terdiri atas hati, limpa, ginjal, jantung, paru-paru dan tenggorokan, dikeluarkan dan dipisahkan dari lemaknya, ditimbang sebagai bobot offal merah. Alat pencernaan seperti usus dan babat dibersihkan isinya lalu ditimbang sebagai bobot offal hijau kosong. Bagian karkas ditimbang sebagai bobot karkas.

\section{Pengolahan Data}

Data yang diperoleh dianalisis dengan metode t-test sampel ganda dengan membandingkan antara kerbau Rawa dengan sapi PO. Model matematika dari metode ini adalah (Stell dan Torrie 1991):

Tabel 1 Komposisi dan kandungan nutrisi pakan ternak berdasarkan bahan kering (Biatin 2012)

\begin{tabular}{lccccccc}
\hline Sumber Pakan & \multicolumn{7}{c}{ Zat-zat makanan (\%) } \\
\cline { 2 - 7 } & BK*) & Abu*) & LK $\left.^{*}\right)$ & PK $\left.^{*}\right)$ & SK $\left.^{*}\right)$ & BETN**) & TDN**) \\
\hline Hijauan & 12,99 & 9,24 & 3,46 & 14,55 & 26,10 & 46,65 & 60,14 \\
Konsentrat & 78,02 & 12,79 & 4,29 & 6,15 & 15,60 & 61,16 & 64,95 \\
Kulit ari tempe & 26,02 & 3,4 & 0,33 & 16,74 & 53,08 & 26,45 & 51,87 \\
\hline Total & 31,21 & 7,61 & 2,37 & 13,75 & 34,79 & 41,47 & 54,48 \\
\hline
\end{tabular}

Keterngan: *Berdasarkan hasil analisis proksimat, $* *$ Berdasarkan perhitungan. 


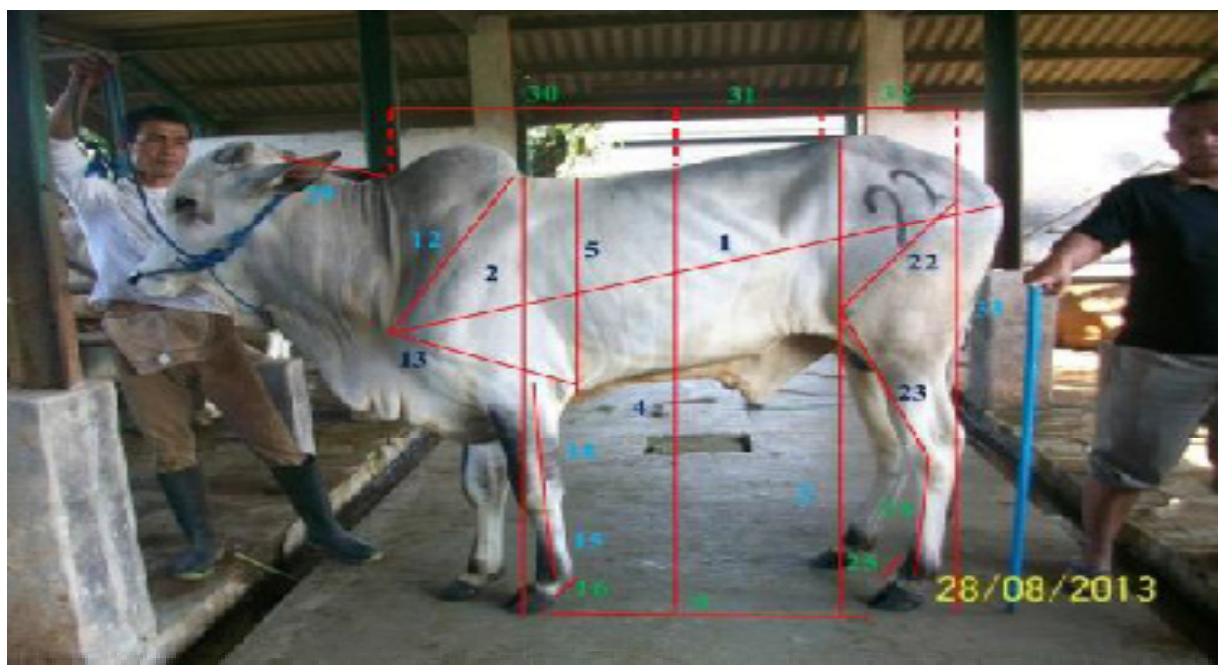

Gambar 3 Ilustrasi pengambilan data morfometrik ternak

Derajat bebas $=2(\mathrm{n}-1)$

$$
\begin{aligned}
& S_{Y 1-Y 2}=\sqrt{\frac{2 S^{2}}{n}} \\
& S=\frac{\left[\sum Y_{1}^{2}-\left(\sum Y_{1}\right)^{2} / n_{1}+\left(\sum Y_{1}^{2}-\left(\sum Y_{2}\right)^{2} / n_{2}\right)\right]}{\left(\left(n_{1}-1\right)+\left(n_{2}-1\right)\right)}
\end{aligned}
$$

Keterangan :

$\mathrm{Y} 1$ = Rataan peubah yang diamati pada sapi PO (n1)

Y2 = Rataan peubah yang diamati pada kerbau rawa (n2)

$\mathrm{S} 2$ = Ragam dari contoh

$\mathrm{n}=$ Jumlah pengulangan

\section{HASIL DAN PEMBAHASAN}

Kerbau adalah ruminansia besar yang mempunyai potensi tinggi dalam penyediaan daging. Kerbau merupakan ternak asli daerah panas dan lembab, khususnya daerah belahan utara tropika. Kerbau ditinjau dari habitatnya, digolongkan dalam 2 tipe, yaitu: swamp bufallo dan river bufallo. Swamp buffalo (kerbau rawa) tipe habitatnya adalah area daerah rawa yang tempat berkubangnya di lumpur, sedangkan river buffalo (kerbau sungai) menetap di daerah basah dan lebih suka berenang di sungai atau kolam yang dasarnya keras. Kerbau sungai umumnya tipe kerbau penghasil susu, sedangkan kerbau rawa merupakan tipe penghasil daging (Fahimuddin 1975). Ciri-ciri kerbau rawa adalah berwarna keabu-abuan, leher terkulai dan memiliki tanduk besar yang mengarah ke belakang sehingga sering digunakan sebagai hewan kerja.

Sapi Peranakan Ongol (PO) merupakan sapi hasil persilangan antara sapi Sumba Ongole dengan sapi setempat di Jawa menghasilkan anakan yang mirip sapi Ongole (Sarwono dan Arianto 2003). Beberapa hasil penelitian menunjukkan sapi PO baik dalam menanggapi perubahan maupun perbaikan pakan. Secara fisiologis sapi PO mempunyai daya adaptasi yang baik terhadap lingkungan tropis (Astuti 2003). Ciri-ciri sapi Ongole menurut Sudarmono dan Sugeng (2008) yaitu, ukuran tubuhnya besar dan panjang, warna tubuhnya putih, tetapi warna leher dan punuk sampai leher berwarna putih keabuabuan sedangkan lututnya hitam. Kepalanya berukuran panjang, sedangkan telinganya agak tergantung, tanduknya pendek dan tumpul yang pada bagian pangkalnya berukuran besar, tubuh ke arah luar belakang. Sapi Ongole juga memiliki gelambir yang lebar, bergantung, dan berlipat yang tumbuh sampai tali pusar. Karakteristik fisik sapi Ongole dari India pada umumnya tidak berbeda dengan sapi PO yang berada di Indonesia (Payne dan Hodges 1997).

Kerbau dan sapi masuk ke dalam filum Chordata, klas Mamalia, ordo Artiodactyla, famili Bovidae, dan genus Bos. Namun, spesies antara kerbau dan sapi berbeda. Kerbau termasuk spesies Bubalus bubalis, sedangkan sapi masuk ke dalam spesies Bos taurus (sapi eropa), Bos indicus (sapi india), dan Bos sondaicus (banteng/sapi bali) (Blakely dan Bade 1991; Fahimmudin 1975). Morfometri merupakan panjang atau ukuran dari bagian tubuh tertentu pada ternak. Morfometri seekor ternak akan berkaitan dengan ukuran karkas dan non karkas dari ternak tersebut. Morfometri biasanya digunakan sebagai penduga bobot ternak. Hal ini sesuai dengan pernyataan Saleh (1982) dan Zubaidah (1994) yang menyatakan bahwa pengukuran ukuran tubuh sering digunakan untuk mengestimasi produksi, misalnya untuk pendugaan bobot badan.

Bobot badan adalah salah satu indikator produktivitas ternak yang dapat diduga berdasarkan ukuran linier tubuh ternak (Kadarsih 2003). Ukuran linier tubuh merupakan suatu ukuran dari bagian tubuh ternak yang pertambahannya sama lain saling berhubungan secara linier. Ukuran linier tubuh ini menurut Minish dan Fox (1979) dapat menjadi tolok ukur dalam memprediksi produktivitas ternak, antara lain panjang badan, tinggi badan, dan lingkar dada. Scanes (2003) menjelaskan bahwa pertumbuhan ternak dapat dideskripsikan dengan mengukur karakteristik fisik ternak seperti bobot badan, tinggi badan, panjang badan, dan lingkar dada. Hanibal (2008) melaporkan bahwa terdapat hubungan antara skor ukuran dan bobot badan, 
Tabel 2 Parameter pengukuran morfometrik tubuh pada ternak hidup (Putra 2012)

\begin{tabular}{|c|c|c|c|}
\hline \multirow[t]{2}{*}{ No. } & \multirow[t]{2}{*}{ Parameter } & \multicolumn{2}{|c|}{ Batas Pengukuran } \\
\hline & & Dari & Hingga \\
\hline 1. & Panjang badan & Tuberculum humerimajus & Tuber ischium \\
\hline 2. & Tinggi badan & $\begin{array}{l}\text { Tempat di bagian caudal os scapula dari titik } \\
\text { dorsal }\end{array}$ & Bidang tempat berdiri ternak \\
\hline 3. & Tinggi hips & Os coxae & Bidang tempat berdiri ternak \\
\hline 4. & Tinggi badan terendah & Pertemuan os thoracic dan lumbar & Bidang tempat berdiri ternak \\
\hline 5. & Dalam dada & $\begin{array}{l}\text { Tepat di bagian caudal os scapulae dari titik } \\
\text { dorsal }\end{array}$ & Os sternum \\
\hline 6. & Jarak kaki depan dengan belakang & Titik belakang kaki depan & Titik depan kaki belakang \\
\hline 7. & Lebar badan & Tuberculum humerimajus kiri & Tuberculum humerimajus kanan \\
\hline 8. & Lebar pinggul & Tuber coxae kiri & Tuber coxae kanan \\
\hline 9. & Lingkar dada & $\begin{array}{l}\text { Tepat di belakang os scapula, melingkar rapat } \\
\text { pada badan }\end{array}$ & - \\
\hline 10. & Lingkar perut besar & $\begin{array}{l}\text { Bagian abodemen terbesar yang merupakan po- } \\
\text { sisi rumen, melingkar rapat pada badan }\end{array}$ & - \\
\hline 11. & Lingkar pinggul & Tuber coxae kiri & Tuber coxae kanan \\
\hline 12. & Panjang os scapula & Titik tertinggi ossavertebra thoracicae & Articulatio scapulohumeri \\
\hline 13. & Panjang os humerus & Articulatio scapulohumeri & Articulatio cubiti \\
\hline 14. & Panjang ossa radiusulna & Tuberositas radii & Ossa capri \\
\hline 15. & Panjang os metacarpale III & Ossa carpi & Os phalanx proximalis \\
\hline 16. & Panjang phalanges depan & Deuclau & Bidang tempat berdiri ternak \\
\hline 17. & Lingkar paha depan & $\begin{array}{l}\text { Sepertiga humerus bagian bawah, melingkar } \\
\text { rapat pada badan }\end{array}$ & - \\
\hline 18. & Lingkar metacarpal & Melingkar rapat di bagian metacarpal & - \\
\hline 19. & Lingkar carpus & Melingkar rapat di bagian carpus & - \\
\hline 20. & Lingkar ischium & Ischium kiri & Ischium kanan \\
\hline 21. & Jarak pubis & Os pubis kiri & Os pubis kanan \\
\hline 22. & Panjang os femoris & Caput assis femoris & Caput fibulae \\
\hline 23. & Panjang ossatibiafibula & Caput fibulae & Os calcanea \\
\hline 24. & Panjang os metatarsal & Pangkal os tarsale III & Os phalanx proximalis \\
\hline 25. & Panjang phalanges belakang & Deuclau & Bidang tempat berdiri ternak \\
\hline 26. & Lingkar paha belakang & $\begin{array}{l}\text { Sepertiga humerus bagian bawah, melingkar } \\
\text { rapat pada badan }\end{array}$ & - \\
\hline 27. & Lingkar tarsus & Melingkar rapat di bagian tarsus & - \\
\hline 28. & Lingkar metatarsal & Melingkar rapat di bagian metatarsal & - \\
\hline 29. & $\begin{array}{l}\text { Panjang tulang leher (ossa verte- } \\
\text { brae cervicales) }\end{array}$ & Batas antara os occipitalis dan os atlas & Pangkal leher bagian dorsal \\
\hline 30. & Panjang os toracis & Pangkal leher & Titik tengah tubuh bagian dorsal \\
\hline 31. & Panjang lumbar & Titik tengah tubuh bagian dorsal & Processus spinosus pertama tulang sacrum \\
\hline 32. & Panjang sacrum & Diukur di sepanjang tulang sacrum & - \\
\hline 33. & Tinggi sacrum bagian belakang & Sacrum & Bidang tempat berdiri ternak \\
\hline
\end{tabular}

sedangkan lingkar dada merupakan penciri dari ukuran tubuh. Darmayanti (2003) menyatakan bahwa bobot badan pada umumnya mempunyai hubungan positif dengan semua ukuran linier tubuh.

Tabel 3 menunjukkan panjang badan, tinggi badan, tinggi hips, tinggi badan terendah, dan lebar badan pada sapi PO lebih besar ukurannya dari kerbau, sedangkan lebar pinggul, lingkar perut besar, dan lingkar pinggul pada kerbau ukurannya lebih besar dari sapi $\mathrm{PO}(\mathrm{P}<0,05)$. Hasil tersebut menunjukkan perbedaan karakteristik tubuh pada kedua jenis ternak. Kerbau rawa memiliki karakteristik tubuh yang lebar dan gemuk, sedangkan sapi PO tinggi dan panjang. Lingkar dada dan lingkar perut besar pada kerbau lebih besar dari sapi. Hasil tersebut berpengaruh terhadap persentase offal merah dan offal hijau pada Tabel 7, pada kerbau lebih besar dibandingkan sapi $(\mathrm{P}<0,05)$.

Aisyah (2000) menyatakan bahwa peubah lingkar dada merupakan parameter yang memiliki nilai koefisien 
Tabel 3 Rataan ukuran bagian tubuh utama kerbau rawa dan sapi PO

\begin{tabular}{lcc}
\hline Parameter $(\mathrm{cm})$ & Kerbau & Jenis Ternak \\
\cline { 2 - 3 } & $218,66 \pm 12,28$ & $217,37 \pm 15,44$ \\
Bobot awal $(\mathrm{kg})$ & $110,94 \pm 3,11 \mathrm{~b}$ & $117,44 \pm 3,37 \mathrm{a}$ \\
Panjang badan & $107,78 \pm 5,49 \mathrm{~b}$ & $124,25 \pm 2,00 \mathrm{a}$ \\
Tinggi badan & $107,39 \pm 3,05 \mathrm{~b}$ & $127,38 \pm 3,26 \mathrm{a}$ \\
Tinggi hips & $106,94 \pm 3,78 \mathrm{~b}$ & $120,38 \pm 8,40 \mathrm{a}$ \\
Tinggi badan terendah & $57,00 \pm 2,77$ & $55,31 \pm 2,37$ \\
Dalam dada & $61,72 \pm 7,44$ & $65,63 \pm 10,49$ \\
Jarak kaki depan dengan belakang & $31,94 \pm 1,88 \mathrm{~b}$ & $32,56 \pm 1,52 \mathrm{a}$ \\
Lebar badan & $37,72 \pm 3,11 \mathrm{a}$ & $31,63 \pm 1,98 \mathrm{~b}$ \\
Lebar pinggul & $156,19 \pm 7,60$ & $150,81 \pm 6,44$ \\
Lingkar dada & $180,75 \pm 5,66 \mathrm{a}$ & $165,50 \pm 4,08 \mathrm{~b}$ \\
Lingkar perut besar & $163,63 \pm 4,41 \mathrm{a}$ & $148,63 \pm 6,38 \mathrm{~b}$ \\
Lingkar pinggul & $14 k a n$ & \\
\hline Ketrangan: angka yang & \\
\hline
\end{tabular}

Keterangan: angka yang disertai huruf yang berbeda pada baris yang sama menunjukkan perbedaan yang nyata $(\mathrm{P}<0,05)$

korelasi paling tinggi terhadap bobot badan. Hal ini disebabkan dengan bertambahnya berat seekor hewan, bertambah besar pula hewan tersebut karena pertambahan bobot badan dan besar badan nyata kearah samping. Lingkar dada kerbau rawa lebih besar dari sapi PO, namun, persentase karkasnya lebih kecil $(\mathrm{P}<0,01)$ dari sapi. Hasil lingkar dada berpengaruh pada persentase bagian offal merah kerbau lebih besar $(\mathrm{P}<0,05)$ dari sapi.

Tabel 4, 5, dan 6 menunjukkan rataan ukuran alat gerak depan, alat gerak belakang, dan sumbu tubuh kedua jenis ternak. Panjang os metacarpal kerbau rawa lebih kecil $(\mathrm{P}>0,05)$ dari sapi $\mathrm{PO}$, berpengaruh terhadap persentase kaki depan kerbau yang lebih kecil dari sapi. Namun, lingkar metacarpal pada kerbau lebih besar $(\mathrm{P}<0,05)$. Panjang os radius ulna dan panjang phalanges depan pada kerbau lebih besar $(\mathrm{P}<0,05)$ dari sapi. Panjang metatarsal pada kerbau lebih kecil $(\mathrm{P}<0,05)$ dari sapi, berbanding lurus dengan persentase kaki belakang kerbau yang lebih kecil $(\mathrm{P}<0,01)$ dari sapi. Karakteristik tubuh kerbau yang lebar dan gemuk dilihat dari lebar ischium lebih besar $(\mathrm{P}<0,05)$ dari sapi. Panjang leher kerbau rawa lebih kecil $(\mathrm{P}<0,05)$ dari sapi $\mathrm{PO}$, hasil ini menunjukkan perbedaan karakteristik kedua jenis ternak, sapi PO lebih tinggi dari kerbau rawa. Panjang os toracis kerbau rawa lebih besar $(\mathrm{P}<0,05)$ dari sapi $\mathrm{PO}$, namun, panjang dan tinggi sacrum kerbau lebih kecil $(\mathrm{P}<0,05)$, serta panjang lumbar kerbau lebih kecil. Ukuran sumbu tubuh pada sapi PO lebih besar dibandingkan kerbau rawa, hal ini dapat diasumsikan bahwa potensi daging loin pada sapi lebih banyak, sedangkan daging cube roll pada kerbau rawa lebih banyak.

Hasil yang berbeda dalam penelitian ini disebabkan bangsa ternak yang berbeda memiliki ukuran tubuh yang berbeda pula (Soeparno 2005). Zakaria et al. (2003) menyatakan bahwa ternak kerbau memiliki kemampuan yang sangat tinggi dalam memanfaatkan pakan berkualitas rendah, pada kondisi pakan yang jelek, setidaknya kerbau dapat tumbuh secara baik dan tahan terhadap musim kering yang panjang (Pathak dan Ranjhan
1979). Praharani dan Triwulanningsih (2004) menambahkan bahwa berbagai faktor yang menyebabkan variasi ukuran kerbau adalah agroekosistem yang berkaitan dengan lingkungan pakan dan eksternal (suhu dan kelembaban). Hal ini sejalan dengan Prawiradipura et al. (2006) yang menyatakan bahwa agroekosistem yang berbeda memiliki kandungan nutrisi yang berbeda.

Karkas adalah tubuh kerbau sehat yang telah disembelih, dipotong kepalanya diantara tulang occipital (os occipitale) dan tulang tengkuk pertama (os atlas), dipotong kaki depan (carpus dan metacarpus) serta belakang (tarsus dan metatarsus), dikuliti, dibuang isi perut dan bagian dalam (jantung, paru-paru, ginjal, hati, usus, babat), dan dipotong ekornya (Dewan Standarisasi Nasional 1995). Sapi potong menghasilkan daging karkas sebanyak 35\% (Kauffman 2001). Kerbau sebagai ternak potong menghasilkan daging yang cukup tinggi, yaitu dengan karkas sekitar 32\% - 44\% (Sunari 2005). Komponen utama karkas terdiri atas tulang, daging, dan lemak (Forrest et al. 1975). Nilai komersial dari karkas ditentukan oleh beberapa faktor, diantaranya: bobot ternak, bangsa, proporsi bagian-bagian non karkas, ransum, umur, dan jenis kelamin

Tabel 4 Rataan ukuran alat gerak depan kerbau rawa dan sapi $\mathrm{PO}$

\begin{tabular}{lcc}
\hline Parameter $(\mathrm{cm})$ & \multicolumn{2}{c}{ Jenis ternak } \\
\cline { 2 - 3 } & $45,83 \pm 2,83$ & Sapi \\
\hline Panjang os scapula & $29,39 \pm 1,83$ & $31,31 \pm 2,03$ \\
Panjang os humerus & $35,22 \pm 2,41 \mathrm{a}$ & $31,63 \pm 4,03 \mathrm{~b}$ \\
Panjang os radius ulna & $17,22 \pm 1,25 \mathrm{~b}$ & $20,69 \pm 2,25 \mathrm{a}$ \\
Panjang os metacarpal & $6,61 \pm 2,19 \mathrm{a}$ & $4,56 \pm 0,96 \mathrm{~b}$ \\
Panjang phalanges depan & $41,06 \pm 3,61 \mathrm{~b}$ & $49,31 \pm 2,80 \mathrm{a}$ \\
Lingkar paha depan & $18,31 \pm 0,96 \mathrm{a}$ & $16,25 \pm 0,85 \mathrm{~b}$ \\
Lingkar metacarpal & $31,17 \pm 5,26$ & $28,75 \pm 1,25$ \\
Lingkar carpus &
\end{tabular}

Keterangan: angka yang disertai huruf yang berbeda pada baris yang sama menunjukkan perbedaan yang nyata $(\mathrm{P}<0,05)$. 
Tabel 5 Rataan ukuran alat gerak belakang kerbau dan sapi PO

\begin{tabular}{lcc}
\hline Parameter $(\mathrm{cm})$ & \multicolumn{2}{c}{ Jenis ternak } \\
\cline { 2 - 3 } & $17,44 \pm 1,21 \mathrm{a}$ & $14,81 \pm 1,96 \mathrm{~b}$ \\
\hline Lebar ischium & $35,50 \pm 2,46$ & $34,88 \pm 1,60$ \\
Jarak pubis & $31,22 \pm 2,37$ & $33,00 \pm 2,36$ \\
Panjang os fomoris & $40,44 \pm 4,91 \mathrm{~b}$ & $46,00 \pm 3,99 \mathrm{a}$ \\
Panjang tulang tibia fibula & $25,11 \pm 1,78 \mathrm{~b}$ & $27,50 \pm 2,04 \mathrm{a}$ \\
Panjang os metatarsal & $6,67 \pm 1,12$ & $7,06 \pm 1,72$ \\
Panjang phalanges belakang & $66,81 \pm 5,07$ & $64,25 \pm 9,75$ \\
Lingkar paha belakang & $35,38 \pm 1,77$ & $32,94 \pm 3,14$ \\
Lingkar tarsus & $19,81 \pm 1,13$ & $18,81 \pm 1,00$ \\
Lingkar metatarsal &
\end{tabular}

Keterangan: angka yang disertai huruf yang berbeda pada baris yang sama menunjukkan perbedaan yang nyata $(\mathrm{P}<0,05)$.

Tabel 6 Rataan ukuran bagian sumbu tubuh kerbau rawa dan sapi PO

\begin{tabular}{lcc}
\hline Panjang $(\mathrm{cm})$ & \multicolumn{2}{c}{ Jenis ternak } \\
\cline { 2 - 3 } & $36,78 \pm 3,30 \mathrm{~b}$ & $42,25 \pm 6,18 \mathrm{a}$ \\
Panjang tulang leher & $50,00 \pm 3,46 \mathrm{a}$ & $33,44 \pm 3,68 \mathrm{~b}$ \\
Panjang os toracis & $23,88 \pm 5,47$ & $25,75 \pm 3,69$ \\
Panjang lumbar & $13,25 \pm 2,31 \mathrm{~b}$ & $15,50 \pm 1,71 \mathrm{a}$ \\
Panjang sacrum & $112,22 \pm 4,55 \mathrm{~b}$ & $131,19 \pm 3,09 \mathrm{a}$ \\
Tinggi sacrum bagian & & \\
belakang & \\
\hline
\end{tabular}

Keterangan: angka yang disertai huruf yang berbeda pada baris yang sama menunjukkan perbedaan yang nyata $(\mathrm{P}<0,05)$

(Berg dan Butterfield 1976). Persentase karkas ditentukan berdasarkan bobot karkas panas, sedangkan bobot karkas dingin mengalami penyusutan sekitar 2\%-3\% dari bobot karkas panas yang hilang sebagai drip (Forrest et al. 1975; Tulloh 1978). Karkas dinyatakan dalam persentase karkas yaitu membandingkan bobot karkas dengan bobot potong. Karkas merupakan komponen tubuh yang mempunyai nilai ekonomis tinggi dan dapat digunakan sebagai satuan prediksi untuk menilai kriteria keberhasilan produksi ternak, yang dinyatakan dalam persentase karkas dan bobot karkas. Soeparno (2005) mengatakan bahwa faktor yang mempengaruhi perkiraan jumlah daging yang dihasilkan karkas adalah ketebalan lemak subkutan, persentase lemak penyelubung ginjal dan pelvis terhadap karkas dan skor konformasi paha.

Tabel 7 menunjukkan persentase karkas pada kerbau rawa lebih kecil dibandingkan sapi PO $(\mathrm{P}<0.01)$, sedangkan persentase non karkas kerbau rawa (19,35\%) lebih besar dari sapi PO (17,93\%). Hal ini disebabkan persentase karkas dipengaruhi oleh bobot potong, bangsa, umur dan pakan (Goodwin 1977). Namun Berg dan Butterfield (1976) dan Soeparno (2005) menyatakan bahwa faktor yang sangat mempengaruhi proporsi dan komponen non karkas adalah pakan. Persentase karkas kerbau menurut Hadjosworo dan Levine (1987) sebesar 46,3\% sedangkan persentase karkas sapi PO sebesar 46,73\%-47,16\% (Ngadiyono 2001).
Hal ini sesuai dengan pernyataan Soeparno (2005) bahwa pertambahan non karkas dipengaruhi oleh pakan, sedangkan bangsa ternak dan jenis kelamin hanya mempunyai pengaruh yang kecil

\section{KESIMPULAN}

Ukuran morfometrik sapi PO dan kerbau rawa berbeda pada beberapa bagian. Hasil pengukuran morfometrik menunjukkan panjang badan, tinggi badan, tinggi hips, tinggi badan terendah, panjang os metacarpal, lingkar paha depan, panjang tulang tibia fibula, panjang os metatarsal, panjang tulang leher, panjang sacrum, tinggi sacrum bagian belakang kerbau rawa lebih kecil dari sapi PO, sedangkan lebar pinggul, lingkar perut besar, lingkar pinggul, panjang os radius ulna, panjang phalanges depan, lingkar metacarpal, lebar ischium, dan panjang os toracis kerbau rawa lebih besar dari sapi PO. Persentase karkas kerbau rawa lebih kecil dari sapi PO. Karakteristik kerbau rawa berdasarkan morfometrik tubuh lebih pendek dan lebar, sedangkan sapi PO tinggi dan panjang. Hal ini berhubungan dengan hasil persentase non karkas pada bagian kaki belakang kerbau rawa lebih kecil, sedangkan offal merah dan offal hijau lebih besar.

\section{DAFTAR PUSTAKA}

Aisyah N. 2000. Studi ukuran tubuh sapi Madura di Desa Samaran, Kecamatan Tambelayan, Kabupaten Sampang, Madura [skripsi]. Bogor (ID): Institut Petanian Bogor.

Astuti M. 2003. Potensi dan keragaman sumberdaya genetic sapi Peranakan Ongole (PO). Wartazoa. 14(4): $30-39$.

Bianti RN. 2012. Performa kerbau rawa dan sapi Peranakan Ongole yang digemukkan secara feedlot menggunakan ransum yang disuplementasi minyak ikan lemuru terproteksi [skripsi]. Bogor (ID): Institut Pertanian Bogor.

Blakely J, Bade DH. 1991. Ilmu Peternakan. Ed ke-4. Srigandono B, penerjemah. Yogyakarta (ID): Gadjah Mada University Pr.

Berg RT, Butterfield RM. 1976. New Concepts of Cattle Growth. Sidney (AU): University Pr.

Darmayanti D. 2003. Kualitas karkas serta sifat fisik dan sensori daging domba Lokal pada kecepatan pertumbuhan yang berbeda [skripsi]. Bogor (ID): Institut Pertanian Bogor.

[DSN] Dewan Standarisasi Nasional. 1995. SNI 013933-1995. Karkas Kerbau. Jakarta (ID): Dewan Standarisasi Nasional.

Fahimuddin M. 1975. Domestic Water Buffalo. Gulab Primlani, penerjemah. New Delhi (IN): IBH Publishing Co.

Forrest JC, Aberle ED, Hedrick HB, Judge MD, Merkel RA. 1975. Principles of Meats Science. San Francisco (US): W.H. Freeman and Co.

Frandson. 1992. Anatomi dan Fisiologi Ternak. Yogyakarta (ID): Gadjah Mada University Pr. 
Tabel 7 Persentase karkas dan non karkas kerbau rawa dan sapi PO

\begin{tabular}{lcc}
\hline Parameter (\%) & Kerbau & Senis ternak \\
\cline { 2 - 3 } & \multicolumn{2}{c}{ Sapi } \\
\hline Bobot awal (kg) & $218,66 \pm 16,28$ & $217,37 \pm 15,44$ \\
Karkas & $46,49 \pm 1,95 \mathrm{~B}$ & $52,09 \pm 2,37 \mathrm{~A}$ \\
Non karkas & $19,35 \pm 1,01$ & $17,93 \pm 1,47$ \\
Kepala & $5,74 \pm 0,46$ & $5,42 \pm 0,52$ \\
Kaki depan & $0,59 \pm 0,04$ & $0,65 \pm 0,08$ \\
Kaki belakang & $0,59 \pm 0,05 \mathrm{~B}$ & $0,78 \pm 0,13 \mathrm{~A}$ \\
Ekor & $0,16 \pm 0,02 \mathrm{~B}$ & $0,31 \pm 0,02 \mathrm{~A}$ \\
Kulit & $9,89 \pm 1,43$ & $10,37 \pm 1,01$ \\
Offal hijau & $4,16 \pm 0,20 \mathrm{a}$ & $3,82 \pm 0,31 \mathrm{~b}$ \\
Offal merah & $4,02 \pm 0,38 \mathrm{a}$ & $3,38 \pm 0,39 \mathrm{~b}$ \\
Lemak perut & $3,49 \pm 0,37$ & $2,68 \pm 1,11$ \\
\hline
\end{tabular}

Keterangan: angka yang disertai huruf kecil yang berbeda pada baris yang sama menunjukkan perbedaan yang nyata $(\mathrm{P}<0,05)$; angka yang disertai huruf besar yang berbeda pada baris yang sama menunjukkan perbedaan yang sangat nyata $(\mathrm{P}<0,05)$

Goodwin DH. 1977. Beef Management and Production. London (GB): Hutchinson of London.

Hadjosworo PS, Levine JM. 1987. Pengembangan Peternakan di Indonesia. Jakarta(ID): Yayasan Obor Indonesia.

Hanibal MV. 2008. Ukuran dan bentuk serta pendugaan bobot badan berdasarkan ukuran tubuh domba silangan lokal garut jantan di Kabupaten Tasikmalaya [skripsi]. Bogor (ID): Institut Pertanian Bogor.

Kadarsih S. 2003. Peranan ukuran tubuh terhadap bobot badan sapi bali di propinsi Bengkulu. Jurnal Penelitian UNIB. IX (1):45-48.

Minish GL, Fox DG. 1979. Beef Production and Management. Reston, Virginia(US): Reston Publishing Co., Inc. \& A Prentice-Hall Co.

Ngadiyono N. 2001. Produksi dan kualitas daging sapi Peranakan Ongole jantan yang dipelihara dengan bobot awal dan lama penggemukan yang berbeda. $\mathrm{Bul}$. Peternakan. 8(1): 27 - 56.

Pathak NN, Ranjhan SK. 1979. Management and Feeding of Buffaloes. New Delhi (IN): Vikas Publishing House PVT Ltd.

Payne WJ, Hodges J. 1997 Tropical Cattle, Origins, Breeds and Breeding Policies. Oxford (GB): Blackwell Science Ltd.

Praharani L, Triwulanningsih E. 2008. Karakteristik bibit kerbau pada agroekosistem daratan tinggi. Pros. Seminar dan Lokakarya Nasional. Puslitbang Peternakan, Bogor. Hlm 113-123.

Putra BW. 2012. Performa anatomis dan produktivitas serta kualitas karkas domba ekor tipis jantan dengan Genotipe Calpastatin (CAST-1) yang berbeda [tesis]. Bogor (ID): Institut Pertanian Bogor.

Saleh AR. 1982. Korelasi antar bobot badan, lingkar dada, lebar dada, dan dalam dada pada sapi ongole di Pulau Sumba. Media Petern. 7(1): 19 - 36.

Sarwono B, Hariono AB. 2003. Penggemukan Sapi Potong. Jakarta (ID): Penebar Swadaya.

Scanes CG. 2003. Biology of Growth of Domestic Animals.
Iowa (US): Iowa State Pr.

Soeparno. 2005. Ilmu dan Teknologi Daging. Ed ke-4. Yogyakarta (ID): Gadjah Mada University Pr.

Steel RGD, Torrie JH. 1993. Prinsip dan Prosedur Statistik. Suatu Pendekatan Biometrik. Ed ke-2. Sumantri B, penerjemah. Jakarta (ID): Gramedia Pustaka Utama.

Sudarmono AS, Sugeng YB. 2008. Sapi Potong. Jakarta (ID): Penebar Swadaya. Sunari. 2005. Beternak Kerbau. Bandung (ID): Ganeca Exact.

Tulloh NM. 1978. Growth, development, body composition, breeding and management. AAUCS. 59-94.

Zakaria K, Arifin M, Mawai S. 2003. Parameter darah kerbau dara yang mendapat pakan basal jerami padi dan tambahan urea molases. Pros. Seminar Nasional Teknologi Peternakan dan Veteriner. Bogor, 29 - 30 September 2003. Puslitbang Peternakan, Bogor. Hlm. $120-122$.

Zubaidah S. 1994. Pengkajian beberapa cara pendugaan bobot badan sapi perah Fries Holland dengan parameter tubuh [skripsi]. Bogor (ID): Institut Pertanian Bogor. 